\title{
Pengaruh Literasi Keuangan dan Perilaku Keuangan terhadap Keputusan Investasi Mahasiswa
}

\author{
I Wayan Yasa Adi Upadana*, Nyoman Trisna Herawati \\ Universitas Pendidikan Ganesha, Singaraja, Bali, Indonesia \\ *upadana12@gmail.com
}

\author{
Riwayat Artikel: \\ Tanggal diajukan \\ 18 Juni 2020 \\ Tanggal diterima: \\ 18 Agustus 2020 \\ Tanggal dipublikasi: \\ 31 Agustus 2020
}

Kata kunci: Literasi Keuangan, Perilaku Keuangan, Keputusan Investasi, Perbedaan

\section{Pengutipan:}

Upadana, I. W. Y. A., Herawati, N. T. (2020). Pengaruh Literasi Keuangan dan Perilaku Keuangan terhadap Keputusan Investasi Mahasiswa. Jurnal Ilmiah Akuntansi dan Humanika, 10 (2), 126-135

Keywords: Financial Literacy, Financial Behavior, Investment Decisions, Differences

\begin{abstract}
Abstrak
Tujuan dari penelitian ini untuk mengetahui dan mengukur bagaimana pengaruh Literasi Keuangan dan Perilaku Keuangan terhadap Keputusan Investasi Mahasiswa dan juga perbedaan keputusan investasi antara mahasiswa Universitas Udayana dan Universitas Pendidikan Ganesha. Penelitian ini bersifat kuantitatif atau berkaitan dengan angka sebagai tolak ukurnya. Data dikumpulkan dengan cara menggunakan angket atau kuisioner dengan menggunakan teknik random sampling yang disebarakan kepada 200 responden atau mahasiswa. Dalam penelitian ini peneliti menggunakan teknik analisis data deskriptif, uji regresi dan uji beda t-test dengan bantuan program software SPSS versi 24. Hasil penelitian ini menunjukan bahwa literasi keuangan berpengaruh positif terhadap keputusan investasi. Perilaku keuangan berpengaruh positif terhadap keputusan investasi. Hasil dari penelitian ini juga menunjukan tidak terdapat perbedaan keputusan investasi mahasiswa.
\end{abstract}

\begin{abstract}
The purpose of this study is to find out and measure how the influence of Financial Literacy and Financial Behavior on Student Investment Decisions and also the differences in investment decisions between students of Udayana University and Ganesha Education University. This research is quantitative or related to numbers as a benchmark. Data were collected using a questionnaire or questionnaire using random sampling techniques distributed to 200 respondents or students. In this study, researchers used descriptive data analysis techniques, regression tests and t-test different tests with the help of SPSS software program version 24. The results of this study indicate that financial literacy has a positive effect on investment decisions. Financial behavior has a positive effect on investment decisions. The results of this study also showed that there were no differences in student investment decisions.
\end{abstract}

\section{Pendahuluan}

Masyarakat Indonesia pada umumnya mengalokasikan uang atau pendapatannya kebeberapa bentuk seperti konsumsi, simpanan dan investasi. Dari pengalokasian dana tersebut jenis pengalokasian dana yang paling bermanfaat untuk masa yang akan datang adalah jenis investasi. Menurut (Pritazahara \& Sriwidodo, 2015) merencanakan sebuah investasi dalam pengelolaan keuangan pribadi merupakan hal yang krusial bagi setiap individu pada saat ini, ini dikarenakan investasi juga termasuk sebuah proses belajar untuk mengatur keuangan dimasa sekarang dan masa depan.

Sebuah hasil riset dari lembaga riset pemasaran menemukan bahwa rata-rata masyarakat Indonesia hanya melakukan kegiatan menabung dan investasi menggunakan $13 \%$ dari pendapatannya. Dari pendapatan yang digunakan untuk menabung dan 
berinvestasi persentase tabungan lebih besar dari investasi. Dengan jumlah penduduk 4,36 juta jiwa, Provinsi Bali seharusnya memiliki peluang jumlah investor yang cukup tinggi akan tetapi pada prakteknya jumlah penduduk yang memiliki SID hanya sejumlah 21.970 orang, tetapi kabar baiknya terjadi pertumbuhan jumlah investor ber SID setiap tahunnya.

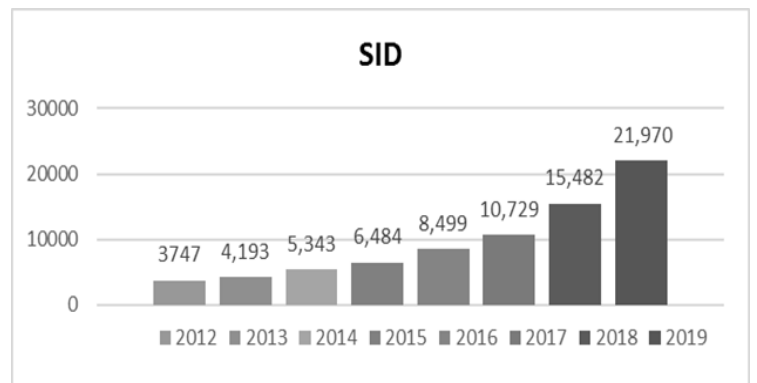

Gambar 1. Jumlah Investor Provinsi Bali

Menurut Tan, (2009) terdapat berbagai jenis-jenis atau produk investasi yang mana setiap jenis atau produk investasi memiliki resiko serta keutungan yang berbeda-beda seperti emas, deposito, saham, reksadana, obligasi , SUN, property, bisnis dll. Terdapat berbagai alasan seseorang memilih sebuah instrumen investasi seperti pengetahuan, pendapatan, keuntungan, dan resiko (Rasuma Putri \& Rahyuda, 2017). Individu lewat pemahaman keuangan yang bagus cenderung lebih percaya diri dalam menggunakan berbagi jenis instrumen investasi (Herawati \& Dewi, 2020)selain itu dengan pendapatan yang melebihi pengeluaran yang mana salah satu faktornya adalah jenis pekerjaan maka seseorang dapat dengan leluasa memilih instrumen investasi tanpa takut kekurangan modal.

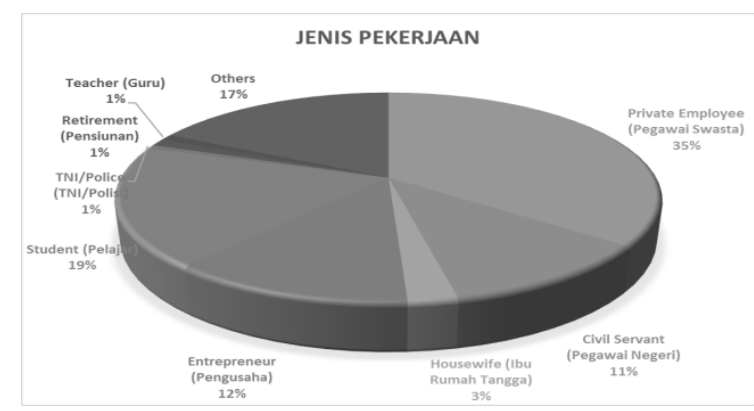

Gambar 2. Jenis Pekerjaan Investor

Berdasarkan grafik data dari BEI menunjukan bahwa persentase kategori investor menurut pekerjaan memiliki perbedaan yang sangat signifikan yang mana pegawai swasta memiliki persentase yang paling tinggi sedangkan guru, anggota TNI/Polri dan pensiunan memiliki persentase yang sangat rendah. Namun yang unik dalam data ini adalah persentase mahasiswa/pelajar yang memiliki Single Investor Identification (SID) cukup tinggi (19\%). Dapat dilihat bahwa mahasiswa/pelajar memiliki kesadaran mengenai pentingnya investasi. Hal ini juga terlihat dari data KSEI atau Kustodian Sentral Efek Indonesia menyatakan bahwa jumlah SID di Indonesia didominasi para milenial dengan rentang umur dibawah 30 tahun sebanyak 44,62\% dari total jumlah investor domestik di Indonesia.

Berdasarkan data tersebut dapat terlihat animo yang sangat besar dari mahasiswa untuk melakukan investasi, namun menurut hasil survey literasi keuangan 3 tahunan OJK menunjukan bahwa dari total mahasiswa yang menggunakan produk keuangan dan investasi hanya $23,4 \%$ yang telah memiliki keterampilan dan perilaku keuangan yang memadai.

Hal yang sama juga dinyatakan oleh presiden Republik Indonesia Jokowi. Beliau menyatakan bahwa literasi dan perilaku keuangan masyarakat indonesia masih tergolong rendah jika disejajarkan dengan negara-negara tetangga. Beliau juga mengungkapkan bahwa indeks literasi keuangan masyarakat indonesia saat ini hanya sekitar 38,03\% masih 
sangat jauh dengan negara-negara tetangga yang indeks literasi keuangannya rata-rata diatas $70 \%$. Sedangkan untuk inklusi atau akses keuangan di Indonesia saat ini yaitu $76,19 \%$. Dari hal ini terlihat bahwa perbandingan antara literasi keuangan dan akses keuangan masyarakat masih sangatlah berbeda jauh. Hal ini sangatlah beresiko dikarenakan banyaknya akses keuangan bagi masyarakat tidak dibarengi dengan meningkatnya pengetahuan keuangan sehingga masyarakat rentan terhadap penipuanpenipuan dalam hal keuangan khususnya investasi. hal ini semakin diperparah dengan kemajuan teknologi sehingga banyak modus-modus penipuan yang bisa membuat masyarakat menjadi korban jika tidak memiliki pengetahuan keuangan yang memadai.

Melakukan sebuah investasi dibutuhkan sebuah keputusan yang tepat dimana setiap keputusan dapat mempengaruhi hasil investasi. Dalam menentukan sebuah keputusan setiap individu akan berperilaku secara rasional dan irasional, tergantung pada informasi yang diperolehnya. Seseorang dengan literasi keuangan yang baik cenderung memiliki kendali lebih baik dalam menentukan sebuah investasi yang beragam karena memiliki banyak informasi keuangan. Misalnya mengetahui kisaran suku bunga dan ketentuan di pasar, memahami bagaimana profil risiko kredit dan situasi pribadi mereka sesuai dengan suku bunga sehingga mereka dapat menentukan investasi mana yang terbaik bagi mereka (Hilgert dkk., 2003)

Lusardi, (2008) menyatakan bahwa perencanaan keuangan yang baik akan dipengaruhi oleh tingkat literasi seseorang. Sedangkan perencannaan investasi dipengaruhi oleh seberapa paham seseorang tentang konsep dasar keuangan . Rikziana \& Kartini, (2017) dalam penelitiannya menyatakan hal serupa yang menyimpulkan bahwa literasi keuangan merupakan faktor yang mempengaruhi pengambilan keputusan investasi seseorang. Hal yang sama juga diungkapkan oleh Herawati \& Dewi, (2020) menemukan bahwa minat seseorang dalam melakukan investasi dipengaruhi oleh literasi keuangannya. Hal ini diperkuat oleh Van Rooij dkk.,(2011) yang dalam penelitiannya menyatakan bahwa masyarakat dengan literasi keuangan rendah lebih enggan untuk melakukan investasi, kalaupun mereka berinvestasi biasanya berdasarkan euphopria sesaat. Keputusan keuangan yang berdasarkan perencanaan serta pengetahuan yang sejalan akan meminimalkan resiko dalam pengambilan keputusan. Hal ini menandakan bahwa semakin tinggi tingkat literasi keuangan maka semakin baik orang tersebut dalam menentukan keputusan investasi.

\section{$\mathbf{H}_{1}$ : Literasi Keuangan Berpengaruh Positif Terhadap Keputusan Investasi.}

Menurut Suryanto, (2017) perilaku keuangan merupakan pola kebiasaan dan tingkah laku seseorang ketika mengatur keuangan pribadinya. Setiap individu akan selalu dihadapkan oleh masalah seberapa besar uang yang diterima dan dikeluarkan. Dalam beberapa kasus terdapat masalah uang yang diterima atau dihasilkan seseorang lebih kecil dibandingkan pengeluarannya hal ini dikarenakan bagaimana perilaku keuangan individu tersebut. Individu dengan perilaku keuangan baik cenderung lebih bijak dan cerdas dalam menggunakan dana atau sumber daya yang dimikinya, seperti mengkontrol belanja, mencatat pengeluaran,dan berinvestasi. Perilaku keuangan dan keputusan investasi adalah dua hal yang saling berkaitan. Nofsinger, (2001) menyatakan dalam definisi perilaku keuangan adalah sebuah ilmu yang mengamati bagaimana seorang individu berperilaku ketika akan melakukan keputusan salah satunya keputusan keuangan. Pengertian tersebut menjelaskan bahwa adanya pengaruh psikologi seseorang ketika melakukan keputusan investasi.

Sehingga dalam hal ini setiap orang tetunya wajib memilki perilaku yang baik ketika menggunakan penghasilan yang seharusnya dihabiskan untuk konsumsi ataupun investasi. Menurut Prawirasasra \& Dialysa, (2015) peran perilaku keuangan ketika seseorang mengambil keputusan investasi sangat penting karena dalam penelitiannya ditemukan bahwa aspek psikologis seseorang sangat berpengaruh terhadap keputusan investasi sejauh mana orang tersebut dapat memaksimalkan keuntungan investasinya. Selain itu dinyatakan bahwa seseorang sangat sulit untuk berperilaku secara konsisten hal ini 
dikarenakan mereka akan membuat setiap asumsi yang berbeda berdasarkan informasi keuangan dan investasi yang diperoleh.

Rikziana \& Kartini, (2017) dalam penelitiannya menyatakan bahwa sebagai respons dari informasi keuangan yang diperolehnya manusia akan mengambil tindakan termasuk keputusan dalam melakukan investasi. Hal yang sama juga terdapat penelitian Baiq Fitriarianti, (2018) dan Aminatuzzahra, (2014) dan Sumtoro \& Anastasia, (2015) yang menemukan bahwa terdapat pengaruh perilaku keuangan dengan keputusan investasi. Dapat terlihat bahwa perilaku keuangan merupakan sebuah respons dari individu mengenai informasi keuangan. Selain itu tingkah laku seseorang dalam mengelola dan melakukan keputusan keuangan pribadinya merupakan dampak dari perilaku keuangannya sendiri. Dari berbagi pernyataan tersebut bisa ditarik kesimpulan bahwa semakin baik perilaku keuangan seseorang semakin baik pula orang tersebut membuat keputusan investasi.

\section{$\mathrm{H}_{2}$ : Perilaku Keuangan Berpengaruh Positif Terhadap Keputusan Investasi.}

Sebagai proses mental, dalam memutuskan atau memilih sesuatu tiap orang memilik perbedaan antara satu dengan yang lain. Seseorang dengan budaya yang berbeda akan mengorganisasi, metransformasi dan bertindak atas suatu informasi dengan cara yang berbeda, termasuk dalam hal keuangan termasuk investasi Keputusan investasi tiap orang tentunnya berbeda-beda hal ini dikarenakan perbedaan presepsi tentang keuangan yang membuat orang cenderung memilih investasi sesuai dengan keyakinan maupun kebutuhannya. Hal ini dikuatkan dengan pernyataan Grable, (2000) yang menyatakan keputusan investasi ditentukan oleh berbagai faktor seperti umur, pendidikan, pendapatan dan pengaruh lingkungan. Hal serupa juga dinyatakan oleh Widayat, (2010) berpendapat bahwa keputusan investasi merupakan hasil interaksi dari lingkungan individu tersebut berada. Disetiap perguruan tinggi tentunya memilki lingkungan sosial budaya, maupun kebiasaan serta pola pikir mahasiswa yang berbeda-beda sehingga menyciptakan perilaku maupun keputusan yang berbeda pula. Menurut Herawati dkk., (2018) perbedaan antara status ekonomi atau tingkat ekonomi seseorang akan berpengaruh terhdap perbedaan presepsi seseorang dalam bersikap khususnya dalam hal keuangan dan investasi.

$\mathrm{H}_{3}$ : Terdapat Perbedaan Literasi Keuangan dan Perilaku Keuangan Mahasiswa S1 Akuntansi Undiksha dan Unud.

\section{Metode}

Penelitian ini merupakan penelitian deskriptif, asosiatif dan komparatif dengan pendekatan kuantitatif yang dimana penelitian ini mengumpulkan, mengolah, menyajikan dan menganalisis data secara kuantitatif dan deskriptif. Populasi yang digunakan dalam penelitian ini adalah mahasiswa S1 Akuntansi Universitas Pendidikan Ganesha Dan Udayana dari angkatan 2016 sampai 2019. Sampel diambil dengan menggunakan teknik Random Sampling. Responden dalam penelitian ini sebanyak 200 orang responden. Sumber data yang digunakan adalah data primer. Teknik pengumpulan data yang dilakukan dengan menggunakan kuisioner dengan metode analisis data menggunakan regresi linier berganda dan uji beda t-test.

Pertama-tama peneliti akan mengumpulkan data dengan instrumen penelitian berupa angket atau kuisioner yang dibagikan kepada para responden. Kemudian akan dilakukan uji validitas dan uji reliabilitas untuk melihat tingkat validitas dan reliabilitas instrumen penelitian. Selanjutnya peniliti akan melakukan uji asumsi klasik sebagai persyaratan sebelum melakukan uji hipotesis dengan menggunakan uji normalitas, multikolinieritas dan heterokedastisitas. Baru selanjutnya peneliti melakukan uji hipotesis dengan menggunakan uji regeresi linier berganda dan uji beda t-test. Dalam mengolah data peneliti menggunakan bantuan dari aplikasi SPSS versi 24.

\section{Hasil dan Pembahasan}

Data penelitian ini diperoleh melalui jawaban responden terhdapa kuisioner yang terdiri dari 200 mahasiswa S1 Akuntansi Undiksha dan S1 Akuntansi Udayana mulai dari angkatan 2016 sampai dengan 2019. Angkatan mahasiswa yang paling banyak mengisi data 
dalam penelitian ini adalah dari angkatan tahun 2016 yang berjumlah 85 orang atau 42,5\%. Mahasiswa angkatan 2019 dengan responden paling sedikit dengan jumlah 28 orang atau $14 \%$ dari total responden. Rentang umur, mahasiswa terdiri dari umur 18 sampai 23 tahun. Dimana pada penelitian ini responden terbanyak berumur 21 berjumlah 67 orang atau 33,5\% dan mahasiswa umur 23 tahun adalah respondnen yang paling sedikit dengan jumlah 4 mahasiswa atau $2 \%$ dari total responden.Berdasarkan jenis kelamin. Sebagian besar mahasiswa merupakan perempuan dengan jumlah 121 (60,5\%). Sedangkan untuk laki-laki berjumlah 79 (39,5\%).

Berdasarkan sumber pendapatan, mahasiswa dibagi menjadi 3 kelompok yaitu rensponden sumber pendapatannya dari orang tua, beasiswa dan bekerja. Dari data yang dipeoleh bahwa sumber pendapatan mahasiswa yang paling banyak yaitu dari orang tua. Selain itu ditemukan juga beberapa mahasiswa yang sumber pendapatannya lebih dari satu. Data yang diperoleh peneliti untuk uang saku mahasiswa ditemukan bahwa paling banyak mahasiswa diberikan uang saku pada rentang Rp.500.000 sampai dengan Rp.2.000.000 perbulan sebesar $63 \%$ dari total mahasiswa. Selain itu ditemukan bahwa terdapat 1,5\% mahasiswa yang tidak mendapat uang saku dari orang tua.Berdasarkan pengeluaran perbulan mahasiswa peneliti menemukan bahwa 131 mahasiswa atau $65,5 \%$ dari total responden memiliki pengeluaran dari rentang Rp.500.000 sampai dengan Rp. 1.000 .000 per bulan dan sisanya memiliki pengeluaran diatas angka tersebut.

Pada penelitian ini ditemukan bahwa 89,5\% mahasiswa pernah melakukan atau sedang berinvestasi sedangkan sisanya $10,5 \%$ tidak pernah melakukan investasi. dari $89,5 \%$ mahasiswa yang melakukan investasi, kebanyakan mahasiswa memilih produk tabungan sebagai sarana investasinya dimana jumlahnya mencapai 127 mahasiswa, sedangkan produk investasi yang paling sedikit menjadi pilihan mahasiswa adalah properti dan obligasi dengan jumlah 2 mahasiswa. Hasil uji kualitas data dalam penelitian ini dapat dikatakan valid dengan nilai pearson correlation atau rhitung >rtabel, diketahui rtabel sebesar 0,138 dan berada pada signifikansi 0,05 dan data yang digunakan juga reliabel dengan nilai Cronbach's Alpha lebih besar dari 0,06.

Dalam uji asumsi klasik menggunakan tiga uji terdiri dari uji normalitas, uji multikolenearitas, dan uji heterokedastisitas. Dalam uji normalitas (Kolmogorov-Smirnov Z) didapatkan hasil nilai asymp. Sig (2 tailed) sebesar 0,200>0,05 yang mana data menunjukan bahwa data berdistribusi normal.Untuk uji multikoleniaritas dapat diketahui bahwa nilai tolerance pada variabel independen memiliki nilai $\mathrm{VIF}<10$ dan nilai tolerance $>0,01$. Dapat terlihat bahwa data bebas dari multikoleniaritas. Hasil uji heterokedastisitas (Rank Spearman) menunjukan Sig.(2-tailed variabel literasi keuangan (X1) sebesar 0,890 dan variabel perilaku keuangan (X2) sebesar 0,515. Karena keduanya lebih besar dari nilai 0,05 sehingga dapat disimpulkan bahwa tidak terjadi masalah atau gejala heterokedastisitas.

Tabel 1. Hasil Analisis Regresi

\begin{tabular}{ccccc}
\hline Variable & $\begin{array}{c}\text { Unstandardized } \\
\text { Coefficients }\end{array}$ & Std. Error & t-Statistik & Sig. \\
\hline X1 (Literasi Keuangan) & 1,35 & 0,383 & 3,525 & 0,001 \\
X2 (Perilaku Keuangan) & 0,43 & 0,080 & 5,375 & 0,000 \\
\hline
\end{tabular}

Sumber : Data Diolah, 2020

Tahap uji kualitas data dan uji asumsi klasik telah diuji sehingga tahap selanjutnya adalah menguji dan interpretasi model regresi. Berdasarkan hasil yang terdapat pada tabel diatas dapat ditentukan rumus persamaan regresi linier berganda, $Y=6,151+1,350 X 1+$ $0,430 \times 2+0,05$

Koefisien regresi Literasi Keuangan (X1) sebesar 1,350 memperlihatkan bahwa literasi keuangan mempunyai pengaruh positif terhadap keputusan investasi, maka setiap kenaikan literasi keuangan (X1) akan dapat meningkatkan keputusan investasi (Y) sebesar 1,350. Koefisien regresi Perilaku Keuangan (X2) sebesar 0,430 memperlihatkan bahwa 
perilaku keuangan mempunyai pengaruh positif terhadap keputusan investasi, maka setiap kenaikan dalam perilaku keuangan akan dapat meningkatkan keputusan investasi sebesar 0,430

Pengujian hipotesis dalam penelitian ini menggunakan uji $t$ (secara parsial). Uji $t$ bertujuan untuk menunjukan bahwa seberapa jauh pengaruh Literasi Keuangan (X1) dan Perilaku Keuangan (X2) secara individual dalam menjelaskan variasi Keputusan Investasi (Y) dengan diperoleh ttabel sebesar 1,391. Berdasarkan hasil diatas untuk variabel Literasi Keuangan diperoleh nilai thitung sebesar 3,525 > dari nilai ttabel sebesar 1,391 dan nilai signifikansi Literasi Keuangan sebesar 0,001 < dari 0,05, hal tersebut berarti $\mathrm{H} 1$ diterima. Disimpulkan bahwa literasi keuangan berpengaruh positif dan signifikan terhadap keputusan investasi mahasiswa

Sedangkan untuk hasil penghitungan variabel Perilaku Keuangan diperoleh nilai thitung sebesar 5,375> dari nilai ttabel sebesar 1,391 dan nilai signifikansi Perilaku Keuangan sebesar 0,000 < dari 0,05, hal tersebut berarti H2 diterima. Disimpulkan bahwa perilaku keuangan berpengaruh positif dan signifikan terhadap keputusan investasi mahasiswa

Tabel 2. Hasil Uji Beda T-test

\begin{tabular}{|c|c|c|c|c|c|}
\hline Variabel & \multicolumn{2}{|c|}{$\begin{array}{c}\text { Levene's Test for Equality of } \\
\text { Variances }\end{array}$} & \multicolumn{3}{c|}{ t-test for Equality of Means } \\
\hline Keputusan Investasi & $\mathrm{F}$ & Sig. & $\mathrm{t}$ & df & $\begin{array}{c}\text { Sig. (2- } \\
\text { tailed) }\end{array}$ \\
\hline
\end{tabular}

Sumber : Data Primer Diolah, 2020

Pada hasil penghitungan uji beda t-test terlihat jelas rata-rata keputusan investasi berbeda antara mahasiswa S1 Akuntansi Unud dengan Undiksha. Tetapi berdasarkan penghitungan statistik perbedaan ini tidak terlihat, dikarenakan dari hasil perhitungan ditemukan $F$ hitung levene test sebesar 0.821 dengan probabilitas 0,366 . Probabilitas lebih besar dari > 0,05 maka dapat disimpulkan bahwa HO tidak dapat ditolak atau memiliki variance yang sama.

Berdasarkan hasil tersebut maka analisis perbedaan harus menggunakan equal variance assumed dari penghitungan menggunakan spss didaptkan nilai t EVA (equal variance assumed) sebesar 2.535 dengan tingkat sinifikan sebesar 0,012 (two tail) > 0,05. Disimpulkan $\mathrm{H} 3$ ditolak atau tidak terdapat perbedaan keputusan investasi mahasiswa $\mathrm{S} 1$ Akuntansi Universitas Udayana dengan mahasiswa S1 Akuntansi Universitas Pendidikan Ganesha.

\section{Hasil dan Pembahasan}

Jenis Produk investasi Pilihan Mahasiswa

Dari hasil analisis deskriptif terhadap responden mahasiswa yang berjumlah 200 orang, terdapat 179 orang mahasiswa atau $89,5 \%$ dari total responden pernah atau masih menggunakan produk investasi sedangkan sisanya 21 orang atau 10,55 tidak pernah menggunakan produk investasi. Dari data data tabungan merupakan produk yang paling banyak dimiliki mahasiswa yang berjumlah 127 orang disusul saham 45 orang, emas 26 orang, bisnis/usaha 20 orang, deposito 17 orang, reksadana 16 orang, obligasi dan properti masing-masing 1 orang mahasiswa.

Dalam wawancara singkat yang peneliti lakukan pada beberapa responden S1 Akuntansi Undiksha dan Unud, mereka masih cenderung menggunakan tabungan sebagai produk investasi karena resikonya sangatlah minim serta dapat dengan mudah dicairkan selain itu fakta yang peneliti temukan adalah mereka tidak terlalu memperhitungkan biayabiaya ataupun kelemahan dalam produk investasi jenis tabungan.

Selain tabungan banyak juga terdapat mahasiswa yang memilih saham sebagai produk investasinya. Dari wawancara singkat yang peneliti lakukan para mahasiswa yang 
tertarik melakukan investasi saham dikarenakan keuntungan yang bisa didapat dari investasi saham sangatlah besar. Selain itu untuk mendaftar menjadi investor saham tidaklah begitu mahal serta syarat-syarat nya sangatlah juga tidak sulit.

$\mathrm{Hal}$ ini dikarenakan program pemerintah yang berjudul "Yuk Nabung Saham" sudah berhasil sampai ke universitas-universitas dalam bentuk galeri investasi. bagi mahasiswa yang tertarik mengetahui ataupun ingin mendaftar menjadi investor bisa berkunjung ke galeri investasi yang ada di kampus mereka.

Dari hasil penelitian diketahui juga bahwa masih sedikit mahasiswa yang melakukan investasi di produk properti dan obligasi hal ini sangatlah wajar diakarenakan untuk bisa masuk ke investasi produk properti dibutuhkan modal yang tidak sedikit. Seperti yang diketahui bahwa kebanyakan mahasiswa masih bergantung terhadap uang saku dari orang tua sehingga akan sulit untuk melakukan investasi yang membutuhkan modal besar.

Berbeda dengan obligasi yang sebanarnya harganya masih bisa dijangkau para mahasiswa, hanya saja mahasiswa tidak begitu mengetahui keuntungan maupun resiko obligasi serta tempat diperjualbelikannya obligasi, padahal banyak sekali obligasi-obligasi yang bisa dibeli oleh mahasisiswa misalnya saja SUN atau surat utang utang negara yang masih bisa dibeli dengan harga 1 jutaan.

\section{Pengaruh Literasi Keuangan terhadap Keputusan Investasi.}

Berdasarkan hasil analisis uji regresi linier berganda, variabel Literasi Keuangan memperoleh nilai thitung sebesar 3,525 > dari nilai ttabel sebesar 1,391 dan nilai signifikansi Literasi Keuangan sebesar $0,001<$ dari 0,05 , hal tersebut berarti bahwa $\mathrm{H} 1$ diterima. Sehingga dapat disimpulkan variabel Literasi Keuangan berpengaruh positif dan signifikan terhadap Keputusan Investasi Mahasiswa.

Huston \& J., (2010) mengartikan literasi keuangan adalah proses pengukuran tingkat pemahaman seseorang dalam mencerna informasi keuangan. Dengan literasi keuangan yang dimiliki dapat mempermudah seseorang ketika dihadapkan untuk menentukan keputusan investasi yang dipilih. Keputusan keuangan yang berlandaskan literasi keuangan yang baik dapat mengantungkan seseorang dalam menghadapi masalah keuangan.

Mahasiswa Jurusan S1 Akuntansi Undiksha dan S1 Akuntansi Udayanna secara umum dapat memiliki literasi keuangan yang baik. Dari hasil data kuisionenr ditemukan bahwa $52 \%$ mahasiswa mampu menjawab soal mengenai literasi keuangan dengan skor tinggi. Hal ini dikarenkan berbagai faktor salah satunya pembelajaran di bangku perkuliahan. Yang mana banyak pelajaran akuntansi yang sangat berkaitan dengan literasi keuangan hal ini menyebabkan mahasiswa secara tidak langsung juga ikut memahami dasar-dasar literasi keuangan.

Hasil penelitian ini sama dengan hasil penelitian Rikziana \& Kartini, (2017) yang menemukan bahwa literasi keuangan dapat membantu seseorang dalam pengambilan keputusan keuangan individu termasuk keputusan investasi. Hasil penelitian Chotimah \& Rohayati, (2015) yang pada penelitiannya meneliti mahasiswa akuntansi juga menemukan bahwa semakin tinggi pengetahuan keuangan seseorang akan mempengaruhi manajemen keuangan seseorang ke tingkat yang lebih baik Penelitian Rasuma Putri \& Rahyuda, (2017)) juga mendukung hasil penelitian menemukan tingkat literasi keuangan dapat mempengaruhi keputusan investasi

\section{Pengaruh Perilaku Keuangan terhadap Keputusan Investasi.}

Berdasarkan tabel diatas untuk variabel Perilaku Keuangan diperoleh nilai thitung sebesar 5,375 > dari nilai ttabel sebesar 1,391 dan nilai signifikansi Perilaku Keuangan sebesar $0,000<$ dari 0,05 , hal tersebut berarti bahwa H2 diterima. Sehingga dapat disimpulkan variabel Perilaku Keuangan berpengaruh positif dan signifikan terhadap Keputusan Investasi Mahasiswa Mahasiswa. Rikziana \& Kartini, (2017) mendefinisikan perilaku keuangan sebagai ilmu yang menggambarkan tentang tingkah laku manusia dalam mengambil sebuah tindakan berdasarkan faktor psikologi dan informasi yang diperoleh di lingkungannya.Seseorang yang efektif dan bertanggung jawab dalam mengeloal keuangan 
pribadinya misalnya melakukan penganggaran dan pencatatan pemasukan dan pengeluaran cenderung memiliki perilaku keuangan yang baik.

Data yang peneliti temukan adalah sebagian besar uang saku mahasiswa S1 Akuntansi masih ditanggung oleh orang tua. Hanya beberapa mahasiswa yang ditanggung oleh beasiswa ataupun mereka menanggung uang saku mereka sendiri lewat bekerja. Ini berarti kebanyakan mahasiswa cenderung hanya mengandalkan uang saku orang tua untuk kebutuhan hidupnya. Sikap mahasiswa dalam mengalokasikan dan menggunakan uangnya dipengaruhi berbagai hal, ada yang ditabung atau dinvestasikan ada juga yang langsung dihabiskan tanpa sisa. Hal ini memperlihatkan bahwa setiap mahasiswa memiliki pandangan yang berbeda dalam penggunaan uang yang dimilikinya

Bagi beberapa mahasiswa, bernvestasi pada suatu produk investasi meruapakan hal yang merepotkan dan tidak mudah, hal ini dikarenakan dibutuhkan komitmen dan usaha serta perilaku keuangan yang baik untuk bisa mendapatkan keuntungan dan bertahan dalam dunia investasi. Hal ini menyebabkan mahasiswa cenderung akan mengabaikan investasi keuangan dikarenakan investasi bukanlah pengeluaran prioritas mereka. Namun data yang peneliti temukan dari mahasiswa S1 Akuntansi Undiksha dan Unud bahwa terdapat 89,5\% mahasiswa sudah memiliki pengalaman berinvestasi sehingga dapat disimpulkan bahwa mahasiswa S1 Akuntansi Undiksha dan Udayana memiliki perilaku keuangan yang yang memadai sehingga dapat menggunakan beberapa produk investasi.

Hasil yang sama juga ditemukan pada penelitian Baiq Fitriarianti, (2018) bahwa perilaku keuangan seseorang dapat mempengaruhi keputusan investasi. hal yang sama juga terdapat dalam hasil penelitian Aminatuzzahra, (2014) yang menemukan bahwa sikap keuangan berpengaruh dalam pengambilan keputusan investasi mahasiswa Magister Manajemen Universitas Diponegoro.

\section{Perbedaan Keputusan Investasi Mahasiswa S1 Akuntansi Universitas Pendidikan Ganesha dan Udayana.}

Dari hasil uji beda independent sample t-tes ditemukan bahwa nilai signifikansi sebesar 0,12 lebih besar dari 0,05 hal ini berarti H3 ditolak. Sehingga dapat disimpulkan bahwa tidak terdapat perbedaan keputusan investasi mahasiswa S1 Akuntansi Universitas Pendidikan Ganesha dengan Mahasiswa S1 Akuntansi Universitas Udayana. Dari hasil tersebut peneliti menemukan bahwa hal ini sejalan dengan teori prespektif keuangan untuk menentukan keputusan, dalam hal ini keputusan keuangan pribadi dengan menggunakan proses kognitif atau mental seseorang untuk memecahkan masalah dan menentukan keputusan keuangan keuangannya. Hal yang sama juga disampaikan oleh Widyastuti, (2012) yang menyatakan manusia sebagai mahkluk intelektual tidak lepas dari sifat, emosi, kesukaan dan berbagai macam hal yang mana hal ini akan mempengaruhi bagaiaman manusia itu mengambil keputusan termasuk keputusan keuanagn dan investasi.

Dari pernyataan-pernyataan tersebut dapat diartikan bahwa mahasiswa dalam menetukan keputusan investasi tidak memiliki perbedaan dikarenakan sama-sama memiliki faktor internal dalam diri seperti mental dan keterampilan yang akan mempengaruhi mahasiswa dalam melakukan menentukan keputusan keuangan dan investasi . hasil ini tidak sesuai dengan pernyataan Widayat, (2010) yang dalam penelitiannya mengemukakan bahwa keputusan investasi merupakan hasil interaksi dari lingkungan individu tersebut berada. Hasil penelitian ini mirip seperti hasil penelitian Aminatuzzahra, (2014) yang pada penelitiannya tidak menemukan perbedaan keputusan investasi seorang pegawai negeri sipil dengan pegawai swasta tetapi bertentangan dengan hasil penelitian Sitorus, (2019) yang dalam penelitiannya menemukan perbedaan minat mahasiswa dalam melakukan keputusan investasi pada setiap universitas.

\section{Simpulan dan Saran}

Berdasarkan penelitian yang telah dilakukan maka dapat disimpulkan bahwa (1) Produk tabungan merupakan produk investasi yang masih kebanyakan mahasiswa gunakan karena resiko dan penggunanannya lebih mudah dibandingkan dengan produk-produk investasi yang lain. (2) Literasi Keuangan berpengaruh positif terhadap Keputusan Investasi 
mahasiswa. Ini dibuktikan dengan nilai signifikansi 0,001 lebih kecil dari 0,05. Jadi dapat disimpulkan semakin tinggi literasi keuangan yang dimiliki mahasiswa maka semakin baik keputusan investasi mahasiswa. (3) Perilaku Keuangan berpengaruh positif terhadap Keputusan Investasi mahasiswa. Ini dibuktikan dengan nilai signifikansi 0,000 lebih kecil dari 0,05. Jadi dapat disimpulkan semakin baik perilaku keuangan mahasiswa maka semakin baik keputusan investasi mahasiswa. (4) Tidak terdapat perbedaan keputusan investasi mahasiswa S1 Akuntansi Undiksha dengan S1 Akuntansi Unud.

Hal ini dibuktikan dengan nilai signifikansi uji independent sample t-test yang sebesar 0,012 lebih besar dari 0,05 , sehingga dapat disimpulkan bahwa tidak terdapat perbedaan keputusan investasi mashasiswa S1 Akuntansi Undiksha dengan Unud.Hasil penelitian ini sangat penting mengingat pada dasarnya dalam menentukan sebuah investasi seseorang mestinya paham tentang produk apa yang sedang mereka gunakan agar terhindar dari iming-iming keuntungan yang menggiurkan tanpa awas terhadap resiko yang akan dihadapi. Dengan memiliki literasi dan perilaku keuangan yang memadai diharapkan mahasiswa maupun masyarakat akan lebih paham dan teliti terhadap informasi keuangan yang beredar saat ini dan mampu dalam menangkap peluang maupun melihat risiko dalam melakukan sebuah keputusan investasi. Diharapkan kepada pemerintah maupun lembaga-lembaga terkait agar lebih mensosialisasikan pentingnya literasi keuangan dan juga kepada lembaga jasa keuangan untuk mengimbangi perkembangan literasi keuangan masyarakat dengan melakukan pengembangan-pengembangan produk investasi yang memudahkan masyarakat. Sehingga masyarakat dapat lebih tertarik untuk berinvestasi. Bagi peneliti selanjutnya disarankan dapat menambah variabel selain literasi dan perilaku keuangan. Selain itu dalam penelitian selanjutnya subjek penelitian bisa menggunakan pegawai dikarenakan jumlah investor yang bekerja sebagai pegawai memiliki jumlah yang cukup banyak

\section{Daftar Rujukan}

Aminatuzzahra. (2014). Persepsi Pengaruh Pengetahuan Keuangan, Sikap Keuangan, Sosial Demografi Terhadap Perilaku Keuangan Dalam Pengambilan Keputusan Investasi Individu. Bisnis Strategi, 23(2), 70-96.

Baiq, Fitriarianti. (2018). PENGARUH LITERASI KEUANGAN, PERILAKU KEUANGAN DAN PENDAPATAN TERHADAP KEPUTUSAN BERINVESTASI. Jurnal Economia.

Chotimah, C., \& Rohayati, S. (2015). Pengaruh Pendidikan Keuangan Di Keluarga, Sosial Ekonomi Orang Tua, Pengetahuan Keuangan, Kecerdasan Spiritual, Dan Teman Sebaya Terhadap Manajemen Keuangan Pribadi Mahasiswa S1 Pendidikan Akuntansi Fakultas Ekonomi Universitas Negeri Surabaya. Jurnal Pendidikan Akuntansi (JPAK), $3(2), 1-10$.

Grable, J. E. (2000). FINANCIAL RISK TOLERANCE AND ADDITIONAL FACTORS THAT AFFECT RISK TAKING IN EVERYDAY MONEY MATTERS. JOURNAL OF BUSINESS AND PSYCHOLOGY, 14(4), 239-248. https://doi.org/10.1023/A

Herawati, N. T., Candiasa, I. M., Yadnyana, I. K., \& Suharsono, N. (2018). Factors That Influence Financial Behavior Among Accounting Students in Bali. International Journal of Business Administration, 9(3), 30. https://doi.org/10.5430/ijba.v9n3p30

Herawati, N. T., \& Dewi, N. W. Y. (2020). The Effect of Financial Literacy, Gender, and Students' Income on Investment Intention: The Case of Accounting Students. 394(Icirad 2019), 133-138. https://doi.org/10.2991/assehr.k.200115.022

Hilgert, M., Hogarth, J., \& Beverly, S. (2003). Household financial management: the connection between knowledge and behavior. Federal Reserve Bulletin, Jul, 309-322. 
Huston, \& J., S. (2010). Measuring Financial Literacy. Journal of Consumer Affairs, 44(2), 296-316. https://doi.org/10.1111/j.1745-6606.2010.01170.x

Lusardi, A. (2008). Financial Literacy: an Essential Tool for Informed Consumer Choice? http://www.nber.org/papers/w14084

Nofsinger, J. R. (2001). Investment Madness: How Psychology Affects Your Investing--and what to Do about it. Financial Times Prentice Hall.

Prawirasasra, K. P., \& Dialysa, F. (2015). Implikasi Behavioral Finance Pada Proses Pengambilan Keputusan Investasi Di Masa Pensiun. Jurnal Sekolah Tinggi IImu Ekonomi, 21-36.

Pritazahara, R., \& Sriwidodo, U. (2015). PENGARUH PENGETAHUAN KEUANGAN DAN PENGALAMAN KEUANGAN TERHADAP PERILAKU PERENCANAAN INVESTASI DENGAN SELF CONTROL SEBAGAI VARIABEL MODERATING. Jurnal Ekonomi Dan Kewirausahaan, 15(1), 28-37.

Rasuma Putri, N. M. D., \& Rahyuda, H. (2017). Pengaruh Tingkat Financial Literacy Dan Faktor Sosiodemografi Terhadap Perilaku Keputusan Investasi Individu. E-Jurnal $\begin{array}{llll}\text { Ekonomi Dan Bisnis Universitas Udayana, } & 3407 .\end{array}$ https://doi.org/10.24843/eeb.2017.v06.i09.p09

Rikziana, Y. P., \& Kartini. (2017). Analisis Tingkay Financial Literacy dan Financial Behavior Mahasiswa S-1 Fakultas Ekonomi Universitas Islam Indonesia. E - Journal Universitas Janabadra, $\quad 7(1), \quad 76-99 . \quad$ http://ejournal.janabadra.ac.id/index.php/jurnalefektif/article/view/249/214

Sitorus, D. S. M. (2019). Analisis Perbedaan Tingkat Financial Literacy Financial Behavior dan Minat Investasi Mahasiswa S1 Manajemen Fakultas Ekonomi dan Bisnis Universitas Sumatera Utara dan Fakultas Ekonomi Univesitas Nomensen.

Sumtoro, A., \& Anastasia, N. (2015). Perilaku Keuangan dalam Pengambilan Keputusan Berinvestasi Properti Residensial di Surabaya. Finesta, 3(1), 41-45.

Suryanto. (2017). Pola Perilaku Keuangan Mahasiswa Di Perguruan Tinggi. Jurnal IImu Politik Dan Komunikasi, VII(1), 11-20.

Tan, I. (2009). Mengenal peluang dibalik permainan saham derivatif.

Van Rooij, M., Lusardi, A., \& Alessie, R. (2011). Financial literacy and stock market participation. Journal of Financial Economics, 101(2), 449-472. https://doi.org/10.1016/j.jfineco.2011.03.006

Widayat. (2010). Penentu Perilaku Berinvestasi. Ekonomika-Bisnis, 1(2), 111-128.

Widyastuti, A. (2012). Behavioural Finance dalam Proses Pengambilan Keputusan. Lmfe Unpad, 1-15. 